\title{
Australia is Facing a Housing Affordability Crisis: Is the Solution to this Problem the Singapore Model of Housing?
}

\author{
John McLaren ${ }^{1}$, Allan Yeo ${ }^{2}$ and Michael Sweet ${ }^{3}$
}

\begin{abstract}
Australia is pricing young buyers out of the housing market. Unfortunately, debt-free home ownership in the retirement years is a key part of the Australian welfare system. This paper provides one possible solution to the current housing predicament of Australia. In doing so, the paper examines the housing strategy in Singapore, where residents are provided with accommodation at a reasonable cost. This strategy is examined and translated for use in Australia. In conclusion the paper proposes that the Singapore model of home ownership is worthy of consideration by the government of Australia.
\end{abstract}

\section{JEL Classification: D14}

Keywords: Housing crisis, Australia, Singapore, Superannuation, housing affordability.

\footnotetext{
${ }^{1}$ Charles Darwin University, Australia.

${ }^{2}$ Sessional lecturer, James Cook University, Singapore Campus, Singapore.

${ }^{3}$ Post graduate research student, Murdoch University, Australia.
} 


\section{Introduction}

The Reserve Bank of Australia (RBA, 2015) in its submission to the Inquiry into Home Ownership by the House of Representatives Standing Committee on Economics stated that the Australian welfare system is designed in such a way that debt-free home ownership in the retirement years is a key part of avoiding poverty in old age. In other words, the current rate at which the Age Pension is paid to eligible retirees is not sufficient unless the majority of age pensioners own their home and do not need to pay a market rate of rent for their accommodation (Yates \& Bradbury, 2010). The Australian government is able to save on welfare for the elderly by the fact that at least a majority of pensioners own their own home. The Reserve Bank also pointed out that the home ownership rate in Australia had remained at a steady rate of 70 percent since the 1960's and that this was in line with many other countries that had home ownership rates between 60 to 80 percent (RBA, 2010; Yates \& Bradbury, 2010). However, the Reserve Bank found that there had been a pronounced decline in home ownership among younger household especially in the 25-34 and 35-44 age groups (RBA, 2010; Yates \& Bradbury, 2010). This is where a potential problem may occur in the next 20 years and beyond for future Australian governments faced with funding an increase in Age Pensions due to a decline in home ownership by retirees and at the same time an ageing population with less taxpayers being able to contribute to the Government's revenue.

The purpose of this paper is to commence with an overview of the current housing situation in Australia and the problems associated with an ageing population. Part two of the paper will assess the housing situation in Singapore, where a mixture of public and private housing provides a home ownership rate that is one of the highest in the world. The paper discusses the way in which the Singapore Government allows homebuyers to use part of their retirement fund to provide the deposit on a new home and cover the monthly mortgage payments. The Singapore model on housing is a combination of two separate initiatives: first, government supported public housing and second, a retirement savings system that supports the financing of public housing in order to ensure that 90.3 percent of citizens own their own home (Phang, 2010). The Singapore Government does not provide an Age Pension for eligible retirees. This means that ensuring that Singapore citizens own their own home is vital for their retirement savings. Part three examines the potential for the Singapore model of housing and retirement funding to apply in Australia. Part four briefly examines some of the legal and political issues that must be overcome for such a model to be adopted in Australia. In conclusion the paper contends that the Singapore model of home ownership and the financing mechanism used to purchase and maintain the home is worthy of consideration for Australia's future. However, there would need to be many changes to the way in which public housing is developed and managed in Australia and the law relating to superannuation funds and their management. 


\section{The Current Situation in Australia}

Every country in the developed world, bar 18 demographic outliers, is facing an ageing population. According to Australian Bureau of Statistics (ABS) figures, in 2007, just 13 percent of Australia's population was aged 65 years and over, with only 1.6 percent of those aged over 80. ABS projections indicate that by 2056, 24 percent of Australia's population will be over 65 with 7.3 percent over 85. By 2046, it is estimated that over one quarter of Australia's population will be aged 65 years and over (ABS, 2009). This ageing population is largely a product of sustained low fertility and increased life expectancy, combined with the approaching retirement age of the world's 'baby boomers' born between 1946 and 1964 (ABS, 2011). A consequence of this ageing population is that the ratio of people working to support those in retirement will significantly decrease: for each older person in 2007, there were five working-age people; whilst in 2056 there will be less than three working-age people for every older person (ABS, 2011). The OECD's Pensions at a Glance 2013 highlights that this declining ratio of workers to retirees is consistent amongst the OECD member countries, with the OECD average ratio tipped to decrease to just 1.9:1 by 2060 (OECD, 2013). This ageing population encountered across the world has a number of significant economic and fiscal consequences.

As older workers retire, their incomes will be reduced while also facing large and important expenses such as health care and retirement accommodation. Those aged over 65 in Australia have some of the lowest incomes in relation to the working population in comparison with the majority of OECD countries (OECD, 2013). According to the same report, Australian retirees also have substantially higher income-poverty rates than the Australian population and the OECD average. If retirees are not self-sufficient, they will have to rely on government assistance to meet expenses. The funding for such expenses will have to be met by the existing labour force or through increases in taxes or government borrowing. The 2010 Intergenerational Report by the Australian Treasury identifies that the ageing population will have substantial economic and fiscal consequences in Australia (Australia to 2050: future challenges, 2010). According to the Treasury, the ageing population is the major factor driving the forecast slowing economic growth due to the decreasing labour force participation and government expenditure required to maintain those in retirement. While Australian government expenditure on health, age-related pensions and aged-care is currently already more than a quarter of total spending, by 2049-2050 it is estimated to increase to almost half of total government spending (Australia to 2050: future challenges, 2010).

\section{A The Australian Retirement System}

The development of a strong retirement system to support an ageing population is vital to minimise government expenditure, lower the tax burden, and reduce the impact of excessive demand on the health and welfare system. As described by the World Bank's 1994 report titled, 'Averting the Old Age Crisis' (World Bank, 1994), the onset of an ageing population across the world is putting increasing strain on the retirement systems and overall economy of these nations: 
'Systems providing financial security for the old are under increasing strain throughout the world. Rapid demographic transitions caused by rising life expectancy and declining fertility mean that the proportion of old people in the general population is growing rapidly' (World Bank, 1994, p.xiii). Extended families and other traditional ways of supporting the old are weakening. Meanwhile, formal systems, such as government-backed pensions, have proved both unsustainable and very difficult to reform. In some developing countries, these systems are nearing collapse. In others, governments preparing to establish formal systems risk repeating expensive mistakes. The result is a looming old age crisis that threatens not only the old but also their children and grandchildren, who must shoulder, directly and indirectly, much of the increasingly heavy burden of providing for the aged (World Bank, 1994).

It is therefore vital that the retirement support system is strong and efficient in order to place the government, retirees, and the workforce in the best position to support an ageing population. The World Bank lists the three pillars of retirement support in establishing a strong foundation for a nation's retirement as the following:

(i) state provision of support through a pension scheme;

(ii) compulsory occupational schemes whereby the employer makes provision for money to be paid into a retirement fund; and

(iii) private voluntary savings (World Bank, 1994).

Australia's retirement system adopts this three-pillar approach to retirement savings through both mandatory and optional saving through a retirement fund referred to in Australia as a 'superannuation fund', combined with a means-tested government pension. Currently in Australia, employers are required to contribute 9.5 percent of the salary or wage paid to an employee and the employee can contribute an extra amount up to a specified limit. (Superannuation Guarantee (Administration) Act (Cth), 1992; Superannuation Guarantee Charge Act (Cth), 1992). The maximum amounts that can be contributed by an employer before additional taxes may be payable are, from 1 July 2015, \$25,000 and \$35,000 if aged over 49 . Superannuation is the second primary source of private wealth in Australia with private investment in owner-occupied housing as the main source of retirement savings (Marriot, 2010). Almost all personal saving in Australia is directed into superannuation or owner-occupied housing. The first pillar of Australia's retirement savings system is the means-tested aged pension, which ensures all Australian's, have access to a safety net level of income throughout their retirement that is considered by the government to be sufficient in order to provide a reasonable minimum standard of living (Australia's Future Tax System Review Panel, 2009).

Being taxpayer funded, the means-tested aged pension is a government expense that will increase along with Australia's ageing population. It is therefore vital that the remaining two pillars are effectively designed to ensure a limited fiscal burden of the aged pension. Because the remaining two pillars, namely an employer sponsored retirement payment and private savings place the 
burden on the private sector and not the public, a greater reliance on these two pillars ensures reduced government expenditure (Pension Review Report, 2009).

The second pillar of Australia's retirement savings system is mandatory savings embodied in the 'superannuation guarantee charge' (SGC). The SGC supports Australia's ageing population problems by requiring the labour force to save for their own retirement expenditure (Kaplow, 2008). The third pillar of Australia's retirement savings system is voluntary savings. Voluntary retirement savings are embodied through voluntary superannuation contributions. These contributions are encouraged by generous tax concessions, but can also be viewed more broadly to include other forms of lifetime voluntary savings such as home ownership. The 2009 'Australia's future tax system' review recognised that while Australia's three-pillar approach to retirement savings is unusual among developed countries, it has considerable strengths in satisfying retirement needs and spreading the risk between the public and private sector in a fiscally responsible manner. The review recommended that the current three-pillar retirement system be preserved and there is no indication that the current Australian government intends to alter the current structure (James, 1994). A similar government inquiry in 2016 into home ownership recommended no change in the federal government's approach to ensuring housing affordability (Commonwealth Parliament, 2016).

\section{B The Fourth Pillar of Retirement Savings - the Home}

Home ownership by Australians has been a major part of the culture. This supports the individual's fundamental need for shelter (Reserve Bank of Australia, June 2015). According to the Productivity Commission, housing forms a large part of the Australian economy and is an integral part of people's wellbeing (The Productivity Commission, 2015). Housing is considered to be the fourth pillar of retirement savings even though it has not been recognised formally in official documents on retirement income policy in Australia. This is given as the reason why the base rate for the Age Pension can be set as low as 25 percent of the Average Weekly Earnings (AWE), which is low by international standards. (Yates \& Bradbury, 2010). The Reserve Bank of Australia also confirms this position and states that the Australian welfare system is designed in such a way that outright (debt-free) home ownership in retirement years is a key part of avoiding poverty in old age (RBA, 2015).

Yates and Bradbury (2010) contend that the question as to whether the retirement income provided by the traditional three pillars is adequate depends on the retirees housing costs. For those 80 percent of retirees owning their own home their after-housing poverty rate is relatively small by international standards. However, the after-housing poverty rates for older retirees not owning their home is significantly worse. Unfortunately, the rate of home ownership in Australia is declining and this will result in a reduction of this fourth pillar and an increase in the level of poverty of older Australians in retirement (Yates \& Bradbury, 2010). According to the Reserve Bank of Australia (2015), there has been a pronounced decline in home ownership among younger households, particularly in the 25-34 and 35-44 age groups. Professor Yates contends that the fourth pillar of Australia's retirement income system will be considerably reduced over 
the next 40 years. This means that unless younger Australians are able to purchase a home during their working life future Governments will have to find more revenue for the first pillar, a means tested age-pension.

\section{Public Housing in Australia}

In Australia, housing stock and housing costs are dominated by market outcomes because 95 percent of housing is privately owned. The social rental housing sector accounts for the other 5 percent of housing (Yates \& Bradbury, 2010). This means that the market determines the price of housing and the rent being paid by the tenant. Yates and Bradbury discuss one of the major consequences of having a dominant housing supply based on the market and the following statement highlights the problem:

Older households who were not able to access (or sustain) home ownership when they were younger are more likely to face high housing costs in their retirement than older households who are homeowners and, as a result, are more likely to have inadequate levels of income to meet their non-housing needs (Yates \& Bradbury, 2010, p.201).

Social or public housing in Australia relies on funding from the Commonwealth Government and the State Housing Authorities and 'not for profit' housing organisations undertake the delivery and management of the housing stock (Jacobs et al 2013).

The Commonwealth Government attempted to generate greater private sector investment in affordable housing through the National Rental Affordability Scheme (NRAS) that was introduced on 1 July 2008. However, the Coalition Government repealed the scheme on 28 May 2015 with the NRAS to end 12 months later (National Rental Affordability Scheme Amendment (Administrative Processes) Regulation 2015), saying that the scheme 'failed to deliver for low and moderate income Australians' (Former Ministers and Parliamentary Secretaries, 2014). Under the NRAS the Australian Government, in conjunction with the States and Territories, provided financial incentives to increase the supply of affordable rental housing; reduce the rental costs for low to moderate income households and to encourage the large-scale investment and innovative delivery of affordable rental housing (Australian Government, Department of Social Services, 2015). The NRAS started on 1 July 2008 and offed annual incentives for a period of 10 years. The NRAS tax incentive is tax-free income and has two components:

- 'a Federal Government contribution in the form of a refundable tax offset or payment to the value of $\$ 8,187.78$ per dwelling per year in $2015-16$, and

- a state or territory contribution in the form of direct financial support or an in-kind contribution to the value of at least \$2,729.26 per dwelling per year' (Australian Government, Department of Social Services, 2015).

Approved participants were eligible to receive the NRAS incentive for each approved dwelling where the conditions of allocation for the dwelling were met including the condition that they are rented to eligible low and moderate-income households at a rate that is at least 20 per cent below 
market value rent. The scheme was popular as an investment because of the tax benefits as shown above. According to Jacobs et al (2013), the NRAS led to 7000 dwellings being provided in the period 2008-2012 with funding for a further 33,000 dwellings being approved under the scheme. Existing dwellings that satisfied the NRAS tests still operate but the tax and financial incentives were only for a ten year period. After that, the owners can then charge a commercial market rent.

Currently the Commonwealth Government provides housing assistance through the provision of finance to State and Territory governments and the Commonwealth Rent Assistance (CRA) program. Tenants of social housing pay rent based on 25 percent of their assessable income whereas CRA recipients pay market rent but receive a transfer payment from the government to offset their rent. The amount of financial assistance depends on the rent being paid by the tenant and the family situation (Australian Government, Productivity Commission, 2015). This means that as market driven rents increase over the years and fewer younger Australian own their home, the Commonwealth Government must face the prospect of providing increased financial assistance for pensioners in the future.

As Jacobs, Berry and Dalton have found with their research, Australia is keen to attract private finance as a means to boost the affordable housing sector; nation states such as Singapore and Korea invest in public housing because it is necessary to maintain economic growth (Australian Government, Productivity Commission, 2015). Should this now become the focus of Australian governments given that the population is ageing and the rate of home ownership in younger Australians is falling? The approach taken to providing affordable housing in Singapore will be examined as a possible alternative to the current system of government support for housing.

\section{The Singapore Model}

Singapore does not have a 'first pillar' of retirement savings, namely a government supported pension scheme. Singaporean citizens rely on the second pillar and third pillar of retirement savings together with their public supported housing in their retirement. They also expect their children to provide financial support. ${ }^{4}$ Retired Singaporean citizens without financial support from their family continue to work if their total savings within their retirement fund is insufficient. Singaporean citizens have a strong second pillar of support through an employer contribution of up to 17 percent of a maximum of $S \$ 6,000$ per month and a 20 percent employee contribution to a maximum of $\$ \$ 6,000$ per month for private sector employee under 55 years of age (Ministry of Manpower, 2015). A Singaporean citizen or a Permanent Resident earning $\mathrm{S} \$ 6,000$ or more each month would contribute to their retirement fund from their own salary an

\footnotetext{
${ }^{4}$ There are strong cultural expectations that the children will repay their parents for their education and maintenance when growing up in the household by providing financial support when the parents have retired. The problems occur when the parents do not have children to provide the financial support or the children refuse or are unable to support their parents.
} 
amount of $S \$ 1,200$ per month. The employer contributions over and above their salary of an amount of $S \$ 1,020$ per month is contributed to their retirement account being a total contribution of $\$ \$ 2,220$ per month with no deductions for income tax. As discussed later in this paper, part of those contributions are used initially to pay the deposit on the citizen's home and then each month to assist in paying the mortgage.

Housing in Singapore consists of a mixture of public housing supported by the government and private housing, which is subject to the market for supply and price. Legal title to the Government supported housing is leasehold title of 99 years and the private housing is freehold title. The Singapore government owns about 90 percent of all land, up from 44 percent in 1960 . The increase in the governments' landholdings are a result of land reclamation, which automatically becomes state land, and a system to compulsorily reacquire privately held land (resumption) at below market prices (Phang, 2010). Public housing in Singapore is immensely important and it is a major part of the fabric of a Singaporean citizen's life. ${ }^{5}$ The Singapore government introduced the subsidised homeownership scheme in 1964 in order to provide affordable apartments at affordable prices (Phang, 2010). About 80.7 percent of residential households in Singapore are living in housing provided by the Housing Development Board of Singapore (HDB). ${ }^{6}$ The Singapore government builds the flats or apartments (Department of Statistics Singapore, 2015). Singapore is the only country in the world where 90.3 percent of residential households own their homes of which 80.7 percent of the people live in HDB apartments (Phang, 2010).

In the 1960s, the majority of the population of Singapore were staying in housing known as 'squatters'. A squatter is a 'settler with no legal title to the land occupied, typically one on land not yet allocated by government' (Oxford Dictionaries, 2016). However, in Singapore in the 1960 's the 'squatters' typically consisted of up to 200 people living in a 'three-storey shop house with one lavatory and two bathrooms' (Chew, 2015, p 163). The living conditions were appalling and since then the Singapore government has transformed the whole landscape into one that is a model for many countries to consider. The HDB was established as a statutory board in 1960 (Housing and Development Act, 2004). As it resolved the housing shortages, its central goals were evolving. The HDB is now vested with the power to build homes, clear land required for redevelopment, resettle families displaced by HDB's clearance of lands, provide loans for the purchase of flats, and run and control HDB flats that were both owner occupied and rented (Housing and Development Act, 2004, s. 13).

\section{A The Philosophy and Objectives of the $H D B$}

The HDB's first objective was to provide housing so that Singaporean citizens would have a sense of belonging to their country (Housing and Development Board, 2010). At that time Singapore was a young nation and since the 1960s the government took the view that home

\footnotetext{
${ }^{5}$ Only a Singaporean citizen is legally entitled to own an HDB apartment.

${ }^{6}$ Also known as the Housing and Development Board
} 
ownership would allow the population to feel that they had a stake in the future growth of Singapore. The Singapore Government believed that this would lead to political stability, especially considering that they only became an independent nation on 9 August 1965. As stated by then Prime Minister, Mr Lee Kuan Yew (Lee, 2000):

My primary preoccupation was to give every citizen a stake in the country and its future. I wanted a home-owning society...

The second objective was to provide its citizens with a supply of affordable housing. The HDB tries to use market pricing when selling its flats but its major task is to design and create new affordable flats. This is supported by the government's initiative to price new flats at about 20 percent below the flat's market price (Tan \& Naidu, 2014), and giving generous housing grants for young married couples who are purchasing both new and resale flats (Housing and Development Act, 2004). Moreover, over the years as the aspirations of Singaporeans has increased, the government extended these subsidies and grants to families who wish to upgrade their flats from a small one or two room flat, ${ }^{7}$ to a bigger four or five room flat (Asia One Business, 2013).

The third objective of the HDB and the government was to view the home as part of the retirement savings for Singaporean citizens. In this way, the home was viewed as being part of the third pillar of retirement savings similar to the situation in Australia. With 80.7 percent of homeowners living in an HDB flat, the government acknowledges that many Singaporeans may be 'asset rich, but cash poor' when they retire (Ngee \& Tsui, 2005).

As Singapore's population ages (Chan, 1999), since 2007 the government has worked to help HDB flat owners increase the price of their homes by allowing them to upgrade their homes or the complete apartment building (Housing and Development Act, 2016). Singaporean HDB flat owners not only have a place they call home but also the government allows the flat to be used as a source of retirement savings when needed. For example, elderly Singaporeans can use their HDB homes to provide income for them when they retire. This include schemes like subletting their HDB flat (Control of Rent Act, 1987), or down-sizing to a smaller apartment, or relocating near their children, or the Lease Buyback scheme where they can sell part of their lease period back to the HDB for regular income. A lack of demand for the reverse mortgages products provided by private banking institutions necessitated that the Lease Buyback scheme function as a publicly funded initiative (Phang \& Helble, 2016).

Even though the HDB flat is public housing, it has constantly reinvented itself to meet the rising expectations of young Singaporeans. These include increasing the quality and improving the materials used for the interior and the exterior of the flats. In addition, each flat is designed with

\footnotetext{
${ }^{7}$ In Singapore HDB flats are described in terms of the number of rooms comprising the number of bedrooms and one lounge room. A three room flat would consist of two bedrooms and one lounge room as well as one bathroom and kitchen.
} 
the surrounding amenities in mind such at its location to train stations, the Mass Rapid Transit rail system (MRT) and schools. This is designed to meet the demands of Singaporeans living in town centres that cater to their everyday needs while at the same time they are encouraged to commute by public transport to work and the schools available for their children are close to where they live. The clearest indicator of the HDB changing to meet the aspirations of Singaporeans comes in the form of the Design, Build and Sell Scheme (DBSS) administered by the Housing and Development Act, (2004) Part IVB and the Housing and Development Act, (2010) S. 65T(2), and the construction of Executive Condominiums (EC's) administered by the Executive Condominium Housing Scheme Act, (1997) s. 3.

The DBSS was a plan by the HDB where state land was sold to private developers, who would design, build, and sell these HDB flats based on the pricing decided by the private developer [Housing and Development Act, (2010), s. 65T(2)]. The DBSS was intended to be of a higher quality than the usual HDB flats build by the government because the private developers could sell them at a higher price, which naturally means the quality of the flats should be better. The other scheme launched by the HDB to meet young Singaporean's rising demand, was the EC. The EC were executive condominiums that were sold under the HDB's guidance. The land is subject to a 99 year lease from the government. This means that though they are condominiums, they are still subjected to HDB rules, which naturally were different from the usual HDB's because these condominiums were targeted at Singaporeans who were from the upper-middle income group [Executive Condominium Housing Scheme Act, (1997) s. 3]. The Singaporean had to show that their monthly household income was not greater than $\mathrm{S} \$ 10,000$ per month (Phang, 2010, p 45). The interesting part about the rules governing these EC flats are that they become fully privatised housing at the tenth year from the Temporary Occupation Permit date (Leong \& Lim, 2014). This means that from year 10 the owners of these ECs are allowed to sell their EC homes, just like owners of freehold title private condominiums. Whereas the owners of HDB flats are required to obtain permission from the HDB before they are sold.

The Singapore government is using housing not only as a tool to cement each Singaporean's 'stake' in the country; they are also using it as a way to promote the pro-family views of the government. For many years, anyone wishing to purchase a HDB flat had to show that the flats would be occupied by a family nucleus [Stamp Duties Act (Chapter 312), 2005, s. 2(b)(b)]. This meant that couples or mature children who were purchasing the flat with their parents were allowed to acquire a flat. However, for many years singles or single parents were not able to purchase a HDB flat if they could not provide the HDB with evidence that a family unit would occupy the flat. However, in 1991 the government decided to allow single Singaporean citizens over the age of 35 to purchase a resale HDB flat (Housing and Development Board, 2016). These were initially restricted to ' 3 room flats' (Today, 2013). However, the rules were slowly relaxed over the years allowing singles to purchase ' 4 room flats' and in 2013 single citizens were allowed to purchase HDB flats in the primary market, rather than just the secondary market. 
Furthermore, an interesting point showing the depth of the HDB's participation into Singaporean's private lives is in the requirement that each block of flats has to be ethnically composed of the 'right' proportion each ethnic group (Housing and Development Board, 2015). This Ethnic Integration Policy (EIP) means that each block of flats has a racial quota where the HDB ensures that each block has a diverse ethnic group that reflects the same diverse ethnic composition as that of Singapore (Koh, 2010). If an owner of an HDB flat wishes to sell their home then they must obtain the consent of the HDB and ensure that the new owner is from an approved racial group. The HDB flat is also used for Singaporeans of different income groups to coexist together. This is achieved by income restrictions for each different type of flat. For example, the income ceiling of Singaporeans who are allowed to purchase the ' 2 room flats' is different from the ' 3,4 , and 5 room flats' (Housing \& Development Board, 2015). This allows for each block or each town centre area to have a mix of people from different social and wealth background in order to integrate the community, thus increasing the social and economic mix between Singaporeans from different occupations.

\section{B Legal Aspects of the Home Ownership in Singapore}

As stated above, the government wanted to clear Singapore of the appalling squatter conditions that existed in the 1960s and the founding Prime Minister, Mr Lee Kuan Yew stated that each Singaporean should have a stake in the country and its future. This would not have been possible without some key laws and rules that the government implemented in order to facilitate the above goal. First, the Land Acquisition Ordinance was passed in 1920 to give the government more authority to acquire and purchase private land for new housing developments. To aid the HDB in building enough flats to re-settle the burgeoning population in Singapore, it was given wide-ranging authority especially in the area of land acquisition; the planning of new towns; the resettling of Singaporeans living in slums; the designs of the flats; and the building and engineering related matters to the building of the flats. This authority was contained in the Land Acquisition Act (1985), the LAA. The LAA allowed large areas of squatter land to be cleared and the squatters re-housed in a HDB flat. This improved the housing conditions for the squatters. Thus, the Land Acquisition Act (1966) repealed the Land Acquisition Ordinance (1920) and gave the government, via the HDB, the authority to quickly repossess private land (HistorySG, 2016). However, since 1973, the owners of land were compensated at market value and in 1988, the Act was amended to allow the compensation to be pegged to the market value. By 1995, all acquisitions were compensated at market rates (Land Acquisition Act, 1985, s. 33).

The Land Acquisition Act did help the government provide a home for every Singaporean citizen because it allowed the land to be acquired at a lower cost. This helped to reduce the cost of building for the HDB apartment complex and it gave every citizen a chance to own a flat. Before the HDB model, owning a property in Singapore was reserved for the rich. 


\section{The Central Provident Fund}

In 1955, prior to the establishment of the State of Singapore, the Central Provident Fund (CPF) was created (Central Provident Fund Act, 2013, Ordinance 34). The CPF was designed not only to provide a social network of funds available for a Singaporean when they retire, but it was used as a complementary tool with the Land Acquisition Act to allow every Singaporean to be able to purchase a public flat. The CPF started as a state managed compulsory retirement savings plan for workers in 1955. At the start, its core purpose is to ensure that employees who retire have adequate retirement funds when they stopped work at 55 years of age (Central Provident Fund Act, 2006, $\operatorname{Rg} 31$ ). To ensure this both employers and employees contribute a percentage of the employee's pay into the employee's CPF account while the employee was working. Whilst the CPF maintains a monopolistic interest in Singaporean citizens' basic superannuation savings, additional investment for retirement can be made under the Supplementary Retirement Scheme, where private providers invest deposited funds for the benefit of superannuants (Supplementary Retirement Scheme, 2017).

The percentage of contribution has been changing over the years, and most of the time the changes were due to the fluctuating economy. When the economy was not performing well, the government would help employers reduce the cost of labour, by reducing the employer's contribution to the CPF (Gill, 2013). Thus, in some ways, the CPF helps to bring the labour market closer to the equilibrium employment point, when the government feels the need to do so. The biggest contribution of the CPF is it allowed the funds to be used for the construction of government housing. Using supply-side economics, the CPF is the savings fund that allowed the government to tap for investment in what was and is essentially housing (Central Provident Fund Act, 2013). In 1968, the government allowed citizens to use their CPF accumulated contributions to purchase their HDB flat. Together with the Home Ownership Scheme, citizens were highly encouraged to purchase rather than rent their homes (Phang, 2007). This contributed substantially to the ability of Singaporeans to own 'a stake in the country and its future.'

The citizen's CPF contributions can be used in two ways. First, it can be used to help the buyer fund the initial capital deposit needed to secure the home. This is usually 20 percent of the purchase price of the flat (Economic Review Committee, 2001). Second, the CPF can also be used to pay for the monthly home mortgage payment (Central Provident Fund Act, 2013). The impact of allowing the CPF to be used for the initial down payment and the monthly mortgage is far reaching.

First, the home is very affordable because the employer's contribution to the employee's CPF allows the CPF to accumulate quickly funds which were essential for the purchase of a flat. If the buyer purchases a small flat such as a 2 or 3 room flat, the ability to accumulate the initial capital investment for a HDB flat can be achieved as early as 2 or 3 years of employment. Couple this with the HDB's objective to sell newly built homes at a 20 to 30 percent discount to the market 
value of private homes, this dual approach accelerates the speed in which young Singaporean couples can purchase their first own home.

Second, as long as the employee is working, it allows them and the spouse to buy a flat that would be above the category that they would have been able to purchase on their own. For every $\$ 1000$ a Singaporean earns per month, about 15 to 20 percent of their CPF contribution comes from the employer. Assuming a 20 percent contribution from the employer, a Singaporean earning $\$ 4000$ per month acquires an extra $\$ 800 \mathrm{CPF}$ contribution from the employer, which is a substantial sum. The government is giving everyone a chance to own an asset, namely a property of a much higher cost than they would have been able to and this helps the citizen accumulate wealth in the form of their own home, a fourth pillar of retirement savings. This does include the possibility that the homeowner will make a non-taxable capital gain as the price of these homes eventually increases as the Singapore economy grows (Low, 2013). Finally, yet importantly, the CPF was in some way a 'loanable fund' that was used by the government to invest in housing in the form of the HDB (Tison, 1987). The CPF funds, contributed by Singaporean employees and their employers are used to purchase government bonds. These in turn, allowed the HDB to provide loans to citizens when they purchased their flat (Housing \& Development Board, 2015).

The HDB loan rates have been at 2.6 percent for an extensive period (Phang \& Helble, 2016). This allows for the loan repayments to remain stable, which helps to ease any fears of fluctuations that citizens may feel when they are paying their monthly mortgage. Although there are some restrictions in relation to obtaining a loan from the HDB, first time buyers of flats will be allowed to utilise the HDB's loan facilities and the government has made it easy for all Singaporeans to be able to own a flat (Housing \& Development Board, 2015). Thus, this usage of the CPF to finance HDB housing has given the government the ability to avoid selling the flats at market prices and keeping the lending rates on the mortgage on their new HDB flat at a low and constant rate of interest. In 2012, the Government allowed new residential property buyers obtain a mortgage up to a maximum of 35 years.

In order to discourage new owners of HDB flats to sell their property the Singapore Government introduced penalty stamp duty for the vendor. In 2011 the government introduced additional stamp duty on properties sold in the first, second, third and fourth years with the seller paying additional stamp duty of 16 percent; 12 percent; 8 percent and 4 percent respectively. In 2013, the Singapore Government increased stamp duty on the purchase of all real property in Singapore. The stamp duty for all buyers in various categories was increased and the Total Debt Servicing Ratio (TDSR) was introduced in order to prevent buyers purchasing property that they could not afford to service based on their income. There is a waiting period of 3 years for all permanent residents from the receipt of their permanent resident status to be eligible to purchase a resale HDB flat. 


\section{Would the Singapore Model Work in Australia?}

The current housing model used in Australia is a system where 95 percent of the housing is owned and developed by the private sector and subject to market forces. However, young Australians are now facing difficulties in purchasing their own home and the rate of home ownership is falling. The Reserve Bank of Australia foresees major problems in the future if this situation is not remedied. The more important implication is for the age pension to be substantially increased if home ownership is not part of the retirement savings as a fourth pillar. The housing model used in Singapore may provide a solution but there would need to be major changes to the way housing is developed in Australia by governments and the current way in which retirements funds are invested for the future.

\section{A What are the problems if the Singapore model was adopted in Australia?}

There are two main aspects to overcome in adopting the Singapore model. First, the Commonwealth, State, and Territory governments would have to agree on the establishment of a not-for-profit body to be established to construct, sell, and manage the apartments built at a discount price for low income Australians. This could be an extension of the now repealed NRAS supervisory body. This body would be similar to the HDB in Singapore. Second, the superannuation fund would need to be used to pay the deposit on the apartment and possibly part of the monthly contributions to be used for mortgage payments. This would require industry superannuation funds; employer superannuation funds; self-managed superannuation funds and government superannuation funds not only to be allowed to administer these arrangements but also the legislative power to make the withdrawals from the fund. In specific terms, the following changes to the existing law would be required:

1. The Superannuation Industry (Supervision) Act 1993 (Cth) (SIS Act) would need to be amended in order to allow the trustee of the fund to withdraw contributions to pay a deposit on an apartment and to pay the monthly mortgage. Home ownership would have to be acknowledged by the government as forming a major pillar of retirement savings as either a fourth pillar in its own right or as part of the third pillar of private savings. Either way, the investment in the home forms a substantial part of the retirement savings for the Australian citizen. In this way, the home could be viewed as satisfying the sole purpose test pursuant to s 62 of the SIS act because it does form part of the superannuation and related benefits. From the Singapore perspective, the home is definitely considered a major part of the third pillar of retirement savings even if not a separate fourth pillar.

2. In order for younger Australians to be in a position to use part of their superannuation to pay a deposit on their own home, the contributions from the employer will have to be increased from the current 9.5 percent under the Superannuation Guarantee (Administration) Act 1992 (Cth). Employers may have misgivings about doubling their contributions. In addition, the employee will be obliged to make a sizable contribution to the fund, a requirement that may produce less concern from employees as the extra 
contribution will be funding their purchase of a new home. The amounts will need to be similar to the 20 percent rate of the Singapore system. The Australian government should consider removing the 15 percent rate of tax on contributions, and deal with the subsequent revenue shortfall. The total percentage of employer and employee contributions will increase for younger workers and reduce as the worker ages and has paid for their home.

3. Currently the family home is exempt under the assets test for eligibility to receive the age pension. A distinction between the Singapore type of public housing and Australia's private housing is that in Singapore the family home is only exempt under the assets test if it is below a specified value. This is recommended, as older Australian citizens could downsize their family home and purchase a new apartment under the new scheme. That way they free-up capital with which to take advantage of the new stock of affordable housing under the new arrangements. This would reduce the amount of revenue required to service the age pension in the future.

4. The HDB apartment building is developed on leasehold land. The owner is granted a 99 year lease and if they buy an apartment on the secondary market, it will have less than 99 years to run on the lease. Because Singapore is only 51 years old, the government has yet to decide what will happen when the oldest lease ends. In the Australian Capital Territory (ACT), all residential homes are leasehold title for 99 years. This confirms that many Australian home owners are prepared to invest in leasehold title for residential property. Banks and other financial institutions still lend against leasehold title. In 2023, the ACT Government will have to decide what to do about renewing the lease as the oldest blocks of land will be at an end of the 99 years. An issue for Australian governments will be to decide if the new type of affordable housing will be freehold title or leasehold title. In Singapore if the apartment block is in need of a major refurbishment the HDB can move the residents into new apartments on the same conditions that they have and then rebuild the entire apartment block and sell the flats to new citizens requiring a home.

5. In Singapore, the HDB apartment is not part of the estate of the citizen and on their death it is not available to be passed under a will but must be sold. It then becomes available for a new prospective home owner and is not kept as an investment and passed from one generation to another. This attribute of the Singapore system may be seen as being desirable in Australia.

6. In Australia, housing is overwhelmingly the domain of the private sector. The price of housings and rents are market driven. If a Singapore style of public housing is introduced in Australia then the private sector will be contracted to construct the apartment buildings. The only difference is that the property developer will be a government agency and the profit margin will not go to the developer but rather to reduce the price of the apartment. Employment in the housing industry will not be effected. The superannuation system is also dominated by the private sector and by using part of the employee's 
contributions to pay a deposit and the monthly mortgage payments would reduce the amount of funds under management. However, the increase in contributions will offset any reduction. Employment and profit generated under the present system will be maintained.

\section{Conclusion}

Something must be done about the housing affordability problem facing younger Australians. This paper has presented a possible solution based on the Singapore HDB model of housing. It is a form of public housing widely accredited with allowing 80 percent of the population to own their own home, whilst a further 10 percent own homes in the private sector. In all, Singapore has an exceptionally high rate of home ownership, which provides a substantial level of savings for retirement. Given that there is no age pension in Singapore, the Singapore Governments' approach to housing and retirement savings more than compensates for the absence of the first pillar of retirement support, namely a state maintained pension scheme. From this perspective, the Singapore housing model must be seen as very successful and worthy of consideration in Australia. Whilst this paper is a strong proponent of the Singapore model of home ownership, there will need to be many changes in not only the way public housing is developed and managed in Australia but also in the law relating to superannuation funds and their management. 


\section{References}

Asia One Business. (2013). Middle-income get more help to buy flat. Retrieved January 26, 2016, from https://www.orangetee.com/Research/In\%20The\%20News/Middleincome $\% 20$ get $\% 20$ more $\% 20$ help $\% 20$ to\%20buy\%20flat.pdf

Australia's Future Tax System Review Panel (2009). K Henry [Chair], J Harmer, J Piggot, H Ridout and G Smith, Australia's future tax system: The retirement income system (December).

Australian Bureau of Statistics, Feature article: population by age and sex, Australian States and Territories (19 December 2011) Australian Bureau of Statistics http://www.abs.gov.au/ausstats/abs@.nsf/Previousproducts/3101.0Feature\%20Article1Ju $\mathrm{n} \% 202011$ ? opendocument $\&$ tabname $=$ Summary $\&$ prodno $=3101.0 \&$ issue $=\mathrm{Jun} \% 202011 \&$ num $=\&$ view $=$

Australian Bureau of Statistics, Future population growth and ageing (25 March 2009) Australian Bureau of Statistics http://www.abs.gov.au/ausstats/abs@.nsf/Lookup/4102.0Main+Features10March\%20200 9

Australian Government, Department of Social Services, (2015) 'About the National Housing Affordability Rental Scheme.' https://www.dss.gov.au/our-responsibilities/housingsupport/programmes-services/national-rental-affordability-scheme/about-the-nationalrental-affordability-scheme-nras

Australian Government, Productivity Commission, (2015) Productivity Commission Research Paper: Housing Assistance and Employment in Australia.

Australian Taxation Office, (2016), 'National rental affordability scheme - taxation issues'. https://www.ato.gov.au/General/Property/In-detail/Rental-affordability-scheme/Nationalrental-affordability-scheme---refundable-tax-offset-and-other-taxation-issues/

Central Provident Fund Act, Rev. ed, Cap 36, Rg 31, (2006)

Central Provident Fund Act, Rev. ed, Cap 36, (2013)

Chan, A. (1999). Singapore's Changing Structure and the Policy Implications for Financial Security, Employment, Living Arrangements and Health Care. Asian Metacentre Research Paper Series (3).

Commonwealth Parliament - Parliament House, (2016), 'Report on the Inquiry into Home Ownership'

http://www.aph.gov.au/Parliamentary_Business/Committees/House/Economics/Inquiryin toHomeOwnersh/Report

Commonwealth of Australia, The Productivity Commission, (2015), 'Housing Decisions of Older Australians', apo.org.au/files/resource/housing-affordability-crisis-in-sydney-andmelbourne/ 
Control of Rent Act, Rev. ed, Cap 58, (1987)

Department of Statistics Singapore. (2015). Population Trends 2015. Singapore: Department of Statistics, Ministry of Trade \& Industry, Republic of Singapore.

Economic Review Committee. (2001). Refocusing the CPF System for Enhanced Security in Retirement and Economic Flexibility. Singapore: Economic Review Committee.

Executive Condominium Housing Scheme Act, Rev. ed, Cap 99A, (1997)

Gill, A. (2013). Singapore's Fiscal Response to the Great Recession: Radical Innovation or Incremental Change? Singapore: Lee Kuan Yew School of Public Policy.

HistorySG. (2016), Land Acquisition Act is Enforced. Retrieved March 6, 2016, from http://eresources.nlb.gov.sg/history/events/1f669eff-bc82-49d1-a27c-2624e4cab8c6

Housing \& Development Board. (2015). 2-Room Flexi Flats. Retrieved March 6, 2016, from http://www.hdb.gov.sg/cs/infoweb/residential/buying-a-flat/new/2room-flexi-flats

Housing \& Development Board. (2015). Eligibility Schemes. Retrieved March 6, 2016, from http://www.hdb.gov.sg/cs/infoweb/residential/buying-a-flat/resale/eligibility-schemes

Housing and Development Act, Rev. ed, Cap 129, (2004)

Housing and Development Act, Rev. ed, Cap 129, (2010)

Housing and Development Act, Rev. ed, Cap 129, (2016)

Housing and Development Board, (2015). Ethnic Integration Policy and SPR Quota, Retrieved July 16, 2016, from http://www.hdb.gov.sg/cs/infoweb/residential/buying-aflat/resale/ethnic-integration-policy-and-spr-quota

Housing and Development Board (2016). Single Singapore Citizen Scheme, Retrieved July 16, 2016, from http://www.hdb.gov.sg/cs/infoweb/residential/buying-a-flat/resale/singlesingapore-citizen-scheme-or-joint-singles-scheme

Housing and Development Board. (2010). Key Findings of Sample Household Survey 2008. Singapore: Statistics Singapore.

Housing and Development Board. (2015). Housing Loan from HDB. Retrieved July 16, 2016, from http://www.hdb.gov.sg/cs/infoweb/residential/financing-a-flat-purchase/housingloan-from-hdb

Kaplow, L. The Theory of Taxation and Public Economics (Princeton University Press, 2008)

Keith Jacobs, K., Berry M and Dalton T. 'A dead and broken system?: “insider” views of the future role of Australian public housing', (2013) 13(2) International Journal of Housing Policy 183, 187.

Koh, G. (2010). The Quota and its Limitations. Singapore: Lee Kuan Yew School of Policy.

Land Acquisition Act, Rev. ed, Cap. 152, (1985)

Lee, K. (2000). From Third World to First. Singapore: Singapore Press Holdings. 
Leong, P., \& Lim, J. (2014). Executive Condominiums (EC): Special Considerations For Developers. Singapore: Rodyk \& Davidson LLP.

Low, D. (2013). Rethinking Singapore's Housing Policies. Retrieved May 9, 2014, from http://www.ipscommons.sg/rethinking-singapores-housing-policies/

Marriott, L. (2010) 'The Politics of Retirement Savings Taxation: A Trans-Tasman Comparison' $\mathrm{CCH}$.

Ministry of Manpower, www.cpf.gov.sg/Assets/Members/Documents/Jan2016_Con_Rate_Page.pdf

National Rental Affordability Scheme Amendment (Administrative Processes) Regulation (2015).

Ngee, C., \& Tsui, A. K. (2005). Reverse Mortgages as Retirement Financing Instrument: An Option for "Asset-rich and Cash-poor" Singaporeans. Singapore: Singapore Centre for Applied and Policy Economics.

OECD (2013), Pensions at a Glance 2013: OECD and G20 Indicators, OECD Publishing.

Oxford Dictionaries. (2016). Definition of squatter in English. Retrieved January 25, 2016, from http://www.oxforddictionaries.com/definition/english/squatter

Phang, S. (2007). The Singapore Model of Housing and the Welfare State. Singapore: School of Economics at Institutional Knowledge.

Phang, S., \& Helble, M. (2016). Housing Policies in Singapore. Singapore: School of Economics at Institutional Knowledge.

Phang, S.Y. (2010) 'Affordable homeownership policy - Implications for housing markets', (2010) 3(1) International Journal of Housing markets and Analysis 38, 44.

Reserve Bank of Australia, (2015) 'Submission to the Inquiry into Home Ownership', www.rba.gov.au/publications/submissions/inquiry-into-home-ownership/index.html

Stamp Duties Act (2005), Rev. ed, Cap 312.

Superannuation Guarantee (Administration) Act 1992 (Cth).

Superannuation Guarantee Charge Act 1992 (Cth).

Swan, W. MP (2010), 'Australia to 2050: future challenges' (Commonwealth of Australia Attorney General's Department.

Tan, S., \& Naidu, V. L. (2014). Public Housing In Singapore: Examining Fundamental Shifts. Singapore: Lee Kuan Yew School of Public Policy.

The Straits Times (1997). Singapore: Singapore Press Holdings.

Tison, G. S. (1987). The Bid Towards Economic Recovery in the Seacen Countries. The SEACEN Research and Training Centre. 
Today (2013). Singles Over 35 Can Now Buy New HDB Flats. Retrieved March 6, 2016, from http://www.todayonline.com/singapore/singles-over-35-can-now-buy-new-hdb-flats

UN Human Development Report (2005) United Nations Development Programme; Human Development Report 2005: International Cooperation at a Crossroads-Aid, Trade and Security in an Unequal World (2005) United Nations Development Programme.

World Bank (1994). Averting the old age crisis : policies to protect the old and promote growth. Washington DC ; World Bank.

http://documents.worldbank.org/curated/en/973571468174557899/Averting-the-old-agecrisis-policies-to-protect-the-old-and-promote-growth

Yates, J and Bradbury, B. (2010) 'Home ownership as a (crumbling) fourth pillar of social insurance in Australia', (2010) 25 Journal of Housing and the Built Environment 193, 198. 